\title{
EXPLOITATION OF GLASS SAND ON THE OPEN PIT »VRTLINSKA« (MOSLAVINA, CROATIA)
}

\author{
Slavko VUJEC and Borislav PERIĆ \\ Faculty of Mining, Geology and Petroleum Engineering of Zagreb University, Pierottieva 6, Zagreb, Croatia
}

Key-words: Glass sand, Open pit planning, Working and final slopes, Waste dump, Vrtlinska

The exploitation of glass sand in Slavonia and Moslavina has a long tradition. The open pit $\gg$ Vrtlinska» is according to its dimensions and production capacity the biggest one in this regions. Exploitation reserves within this open pit amount about $11000000 \mathrm{t}$ glass sand of a very good quality, and the production capacity is $200000 \mathrm{t}$ yearly according to real needs during design and opening the pit, i. e. before the war. This article discusses geological and geomechanical characteristics of the deposit, as well as the exploitation process, which is considerably matching natural characteristics of the deposit. A more detailed description is given of the planned exploitation phase I above groundwater level which is carried out according to discontinuous system. For the exploitation of the depth part under groundwater level in the phase II, the necessity of further examination of hydrogeological characteristics of the deposit is presented, in order to acquire necessary information on groundwater regime and drainage conditions. Such knowledge will influence the choice of the most appropriate solutions in the exploitation of the depth part of the deposit.

\section{Introduction}

The open pit "Vrtlinska" is the biggest producer of glass sand in our country (Fig. 1). The exploitation of glass sand on this open pit has been carried out since 1988 with the planned capacity of about $200000 \mathrm{t}$ yearly, established according to real economic of the broader area of that time. Because of the war conditions, by the open pit activity only a half of the planed production has been achieved up to now. However, technological solutions are conceptualized in such a way that also bigger quantities than the plane ones can easily be produced, depending on the development and needs of the major consumer, "The Glass Industry Lipik«.

The open pit "Vrtlinska" is situated near C̆azma, within the mining claim of Slavonia, where glass sand has been produced for a long time at the area of Pakrac and Slavonska Požega. According to its dimensions and the shape, the deposit "Vrtlinska« belongs to big deposits of glass sand, whose total worcable reserves amount about 11 million tons. Glass sand is of very good quality. According to the medium content of $93.19 \% \mathrm{SiO}_{2}$ and satisfactory granulometric composition with slight content of harmful constituents, they can be classified as glass sands of the best quality in Croatia, widely applied in glass industry, metallurgy, industry of ceramics, production of abrasives and for other purposes.
Ključne riječi: Kremeni pijesak, Projektiranje površinskih kopova, Radne i završne kosine, Jalovište, Vrtlinska

Eksploatacija kremenog pijeska u Slavoniji i Moslavini ima dugu trađiciju. Površinski kop "Vrtlinska" prema veličini i kapacitetu proizvodnje najveći je u ovim područjima. Eksploatacijske rezerve u granicama ovog površinskog kopa iznose približno 11000000 tona kremenog pijeska vrlo dobre kvalitete, a kapacitet proizvodnje planiran je $200000 \mathrm{t} / \mathrm{god}$. prema realnim potrebama u vrijeme izrade projekta i otvaranja kopa, tj. prije rata. U članku su prikazane geološke i geomehaničke značajke ležišta, te tehnološki proces eksploatacije, koji je u velikom dijelu usklađen $\mathrm{s}$ njegovim prirodnim karakteristikama. Detaljnije je obrađena projektirana eksploatacija I. faze iznad razine podzemne vode, koja se izvodi prema diskontinualnom sustavu. $\mathrm{Za}$ eksploataciju dubinskog dijela ispod razine podzemne vode u II. fazi navedena je potreba detaljnijeg istraživanja hidrogeoloških karakteristika ležišta, u cilju stjecanja nužnih podataka o režimu podzemne vode $\mathrm{i}$ uvjetima odvodnjavanja. Takva saznanja utjecat ce na izbor najpovoljnijih tehnoloških rješenja i eksploatacije dubinskog dijela ležišta.

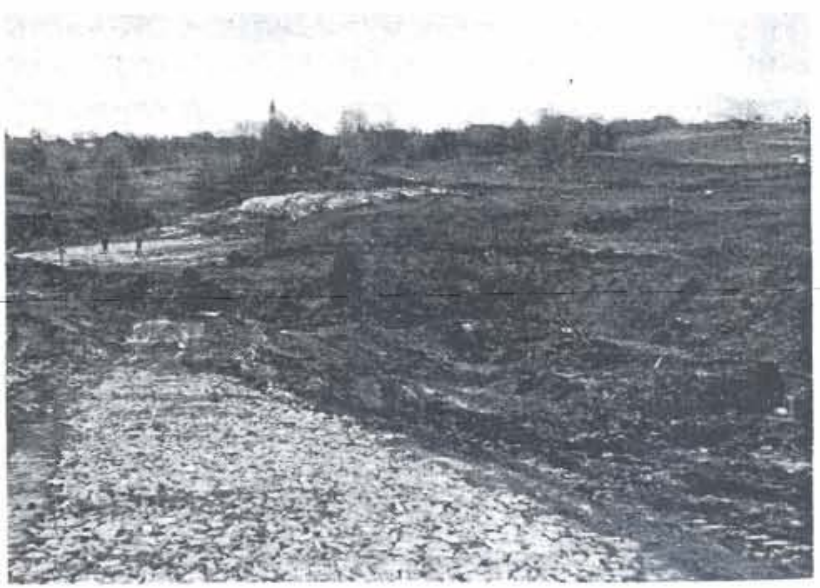

Fig. 1. View of the open pit at opening 1988.

Geological and hydrogeological characteristics of the deposit

Stratigraphically, glass sands of this deposit are of the Pontian age and according to their genesis they are residua developed on the crust of weathered granite rocks of the nord-western marginal area of the Moslavačka gora (Krkalo, 1985). The development of the Pontian sediments begins in weathered zone of granite, which gradually transforms into mica sands and the development of predominantly white middle-coarsed sands follows further in superpositions. Sands generated 


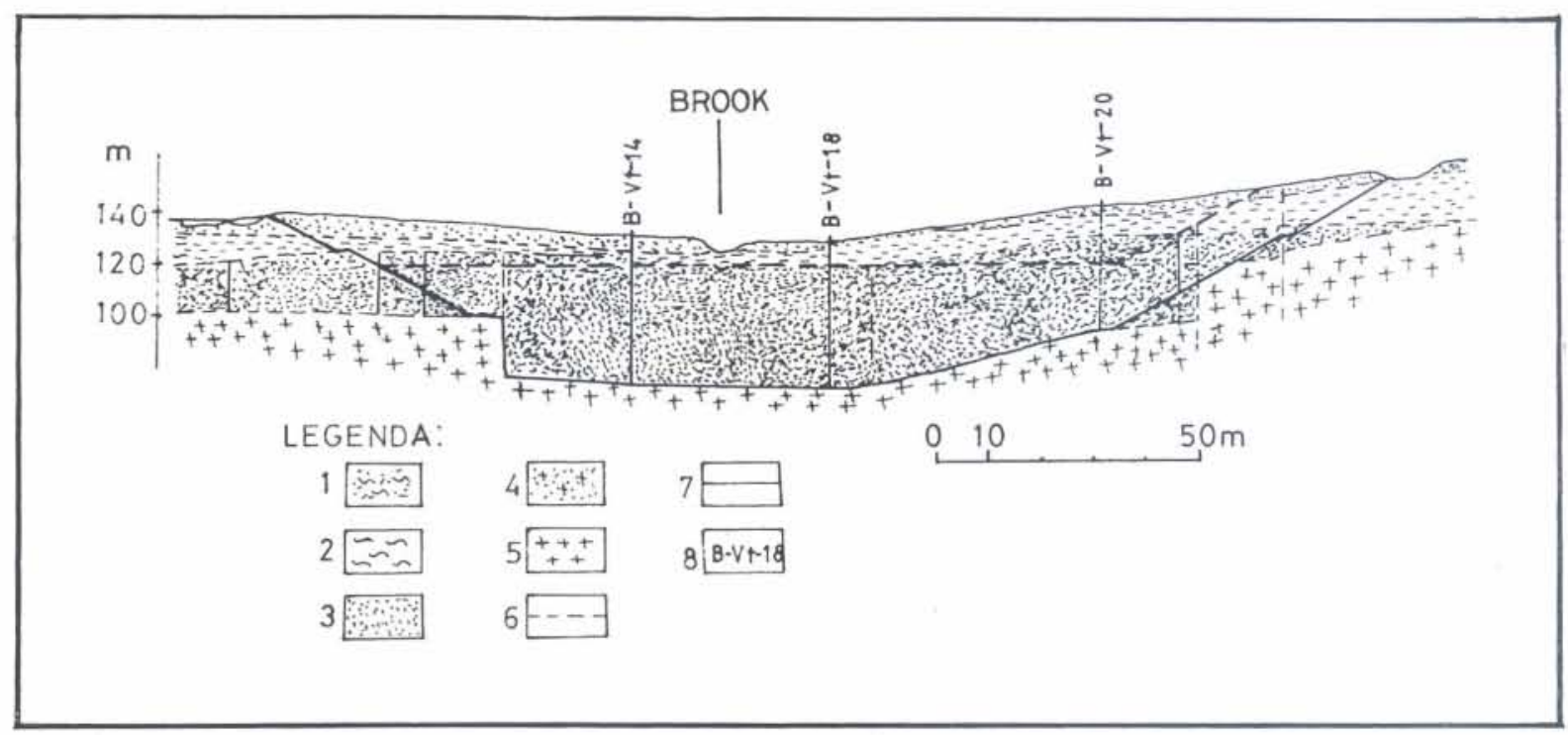

Fig. 2. Characterictis profile of the deposit "Vrtlinska« (after Krkalo, 1985, and Vujec et al., 1987)

1 loess, 2 sandy and silty clays, 3 glass sand, 4 weathered granite zone, 5 granite, 6 pit topography above groundwater level, 7 final pit topography, 8 investigations boreholes.

by granite weathering, are accumulated into tectonically predisposed depression of granite paleorelief.

By exploratory drilling and by the open pit development, the relation of spreding of sand, overlying and underlying strata was established. The deposit has a rather regular shape. Sand sediments are almost horizontal and the bed thickness varies depending on the paleorelief composition and different impact of errosion on the area surface. It is characterized by extremene thickness, which amounts maximum $70 \mathrm{~m}$, and in average for the entire deposit $39 \mathrm{~m}$.

Overlying strata compose a graudal transformation of clayey sands into yellow-brown sandy clays, or are directly developed bedded light-gray clayey marls on white pure sands. Marls are followed by the transition from blue-gray kaolin-montmorillonitic clays to brown sandy and silty clays. On the places where sand is close to the area surface, the Pontian overlying strata are not developed, so loess detritus lies directly on the sand.

On the broader area under exploitation three basic fault types were found, which give the main characteristic of morphostructural set with parquetlike block composition of the field. Fig. 2 illustrates the characteristic geological profile of the deposit "Vrtlinska", and Fig. 3 view 1990.

Differently as other deposits of glass sand in Croatia, the deposit "Vrtlinska " is with its larger part under groundwater level. Deposit is generally drained westwardly, with the overflow elevation $116 \mathrm{~m}$. On the deposit area only one water flow is formed, the brook Ciglenica. In the larger part of the deposit groundwater is subartesian which is the result of slightly permeable overlying strata, practically impermeable underlying strata and tectonically created barrier in western edge.

Hydrogeological characteristics of the deposit are not satisfying for sand exploitation. The estab-

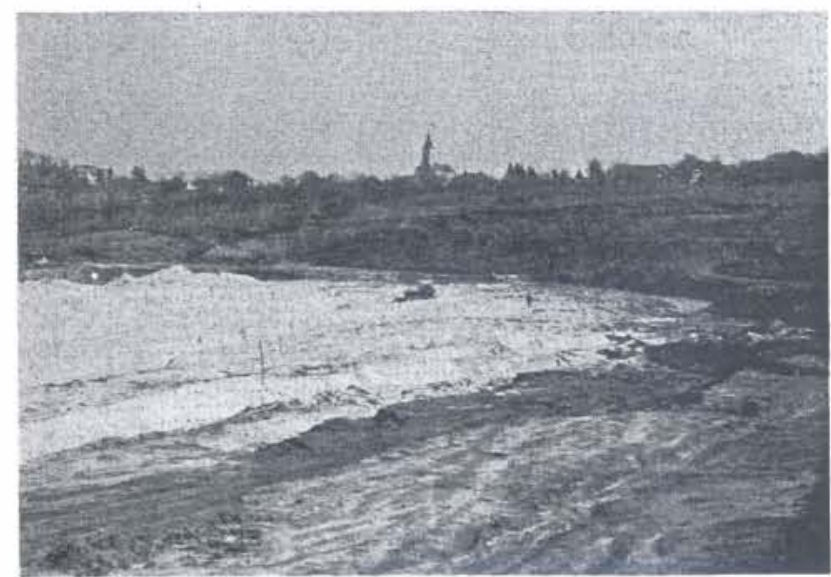

Fig. 3. View of the open pit 1990.

lished groundwater level is rather high, it reaches the elevation $+124 \mathrm{~m}$, thus the larger part of the sand is located under groundwater level. Natural gravitational drainage of the deposit may be achieved only by mining over the elevation $+120 \mathrm{~m}$.

\section{Geomechanical conditions of exploitation}

In order to protect the stability of working and final pit slopes, the extensive examination of geomechanical properties of the overburden strata and sand as well as of the material on the waste dump were carried out during the period of mine design (Vujec et al., 1987).

Stability of the final overburden slope was established under the angle of $25^{\circ}$, and for working slopes a diagram according to particular clay sorts was created depending on the bench heights and stable slope angles.

Sand has a stable final slope angle $35^{\circ}$ independently of bench height, and the angle of working slope $32^{\circ}$ to $35^{\circ}$ depending on water saturation. 
- Foundation of the waste dump must be prepared by cleaning and cascade shaping, and by the creation of drainage trenches in the watered part. Bearing capacity of the foundation was controlled and the stability of the waste dump slopes angle was established to be $25^{\circ}$. Waste dump is bulit in two horizons, the down one bearing $10 \mathrm{~m}$ heigh and the upper one $15 \mathrm{~m}$.

In order to keep necessary stability, it is adviced to conduct efficient drainage of the entire open pit area, to control regularly the dip of the working slopes and to organize periodic inspections and evaluations during its development.

\section{Technological process of exploitation}

Location, shape, size, settling depth and other characteristics of the deposit have influenced the open pit exploitation with a favourable stripping ratio. The results of deposit exploration, especially geological, hydrogeological and geomechanical characteristics pointed to rather complex conditions of the open pit exploitation and the need for possibly most favourable compatibility between technological process and natural properties of the deposit.

The deposit has an irregular trapezoidal shape, its maximum east-western length being around $550 \mathrm{~m}$ and the width in eastern part around $400 \mathrm{~m}$ decreasing westwardly to about $110 \mathrm{~m}$. The plan area of deposit within proved reserves amount $45230 \mathrm{~m}^{2}$. The ground over the deposit is hilly and it raises from its central part from the elevation $128 \mathrm{~m}$ nordwardly to the elevation $150 \mathrm{~m}$, and south-eastwardly to the elevation $160 \mathrm{~m}$. Hanging side of the deposit behaves similarly to the ground morphology and it generally settles gently from east to west under the angle to $5^{\circ}$. The thickness of overburden is the slightest in the central part of the deposit, where it amounts only 3 to 3.8 $\mathrm{m}$. Towards the marginal area, the overburden thickness increase 15 to $30 \mathrm{~m}$. The average thickness of overlying sediments amounts $12.6 \mathrm{~m}$.

By the analysis of natural properties of the deposit, technological conditions and general conceptions of open cut mining, the entire exploitation technology was designed and operated in two basic phases:

PHASE I: Deposit mining above groundwater level, i. e. above the elevation $120 \mathrm{~m}$, in operation

PHASE II: Deposit mining under groundwater level, i. e. under elevation 120 $\mathrm{m}$, collection of data for desing.

Deposit mining above groundwater level is successfully carried out and it covers the height of open pit on which classical way of mining is applied under conditions influencing the determination of technological process, with the stripping ratio $0.7 \mathrm{~m}^{3} / \mathrm{t} \quad\left(1300000 \mathrm{~m}^{3}\right.$ overburden to 1850000 glass sand).

Stripping ratio is more favourable in mining of the depth part of the deposit (in IInd phase) and amounts only $0.2 \mathrm{~m}^{3} / \mathrm{t}$.
Definite boundaries of the open pit on the ground surface are established already in the first mining phase. Geometric indicators of the open pit are established on the basis of geological and geomechanical characteristics of mineral ore body and accompanied rocks, and mining-technological conditions of exploitation. Exploitation technology is acquired according to the up-to-now experience in glass sand exploitation in Slavonia, especially on the open pit Vranić.

Open pit division according to height has not been designed in classical way by forming benches, because the mining technology is based on opening the whole burden on a single bench.

By bulldozer pushing waste is removed to the loading level on the hanging-wall surface of the sand bed. The sand is also by bulldozer pushing and accumulated on the loading level at elevation $120 \mathrm{~m}$ (Fig. 4).

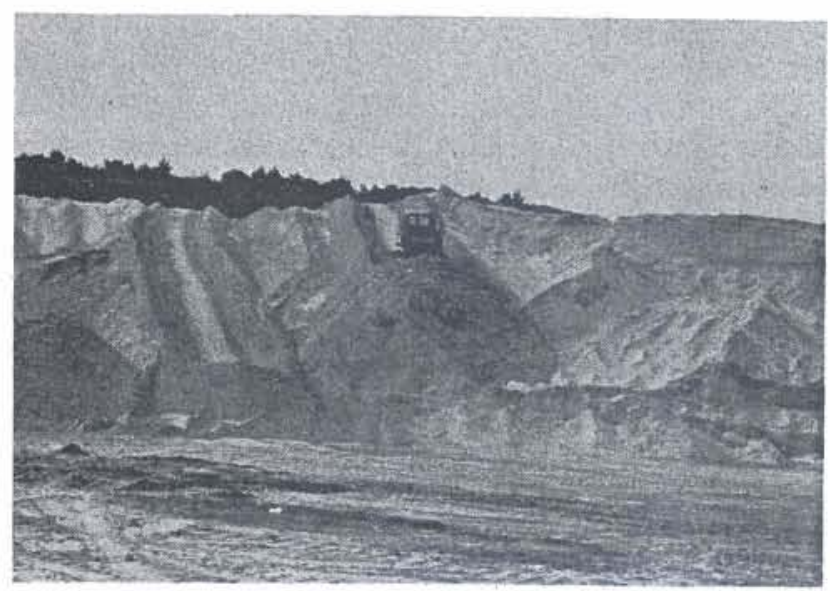

Fig. 4. Bulldozer pushing of sand on the loading plateau

Thereby the heights of overburden and orebody benches vary depending on the thickness of capping and sand above the elevation $120 \mathrm{~m}$. Thus the overburden bench height varies from 5 to 15 $\mathrm{m}$ and the bench height in sand alter from 1 to 20 $\mathrm{m}$.

The construction of working and final slopes of the open pit are illustrated on Figs. 1. 5. and 6.

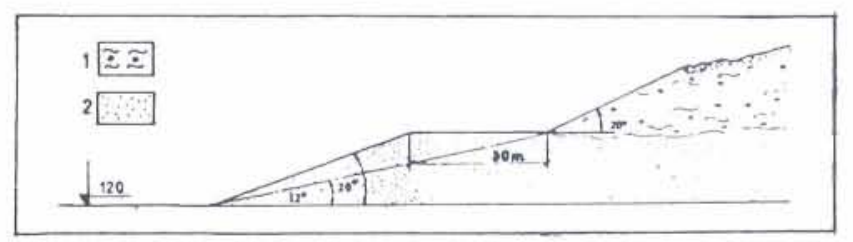

Fig. 5. working slope of the open pit in exploitation phase 1 1 overburden, 2 sand

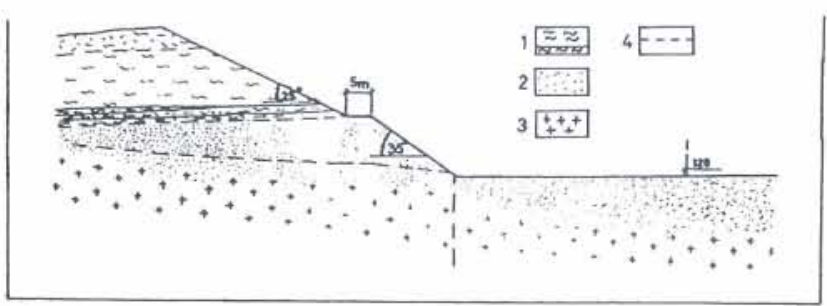

Fig. 6. Final slope of the open pit in exploitation phase I 1 overburden, $\mathbf{2}$ sand, 3 granite $\mathbf{4}$ fault 


\section{Open pit and waste dump planing}

The open pit development was performed in accord with the designed exploration system, production capacity, location of waste dump, and the objects on the area. It is directed from western side, where access towards the deposit is most favourable satisfying in the sense of developing the works, drainage, transportation of waste and sand, and location of mine objects. Within development works a $500 \mathrm{~m}$ long acces road was built from the main traffic road to the deposit, the channels of the brooks Ciglenica and Vrtlinska Jarak were sunk and prepared and a working plateau was created on the basic loading horizon (elevation +120 ), necessary for further development of the open pit (Fig. 7).
The choice of exploitation technology is based on the analysis of the most essential factors influencing the condition of technological process, and there are: natural characteristics of the deposit, quantity of the reserves of mineral raw materials, capacities of production and overburden, location of waste dump, existing experiences in the open pit exploitation of glass sand, characteristics of the mechanization available to the enterpreise a. o. In such a way a discontinued system of winning, loading, transportation and dumping of overburden was chose, as well as a discontinued system of glass sand production by application of the following mechanization: bulldozers, loaders, dump trucks Volvo BM with capacity $9 \mathrm{~m}^{3}$, hydraulic excavator with bucket capacity $2.5 \mathrm{~m}^{3}$, and

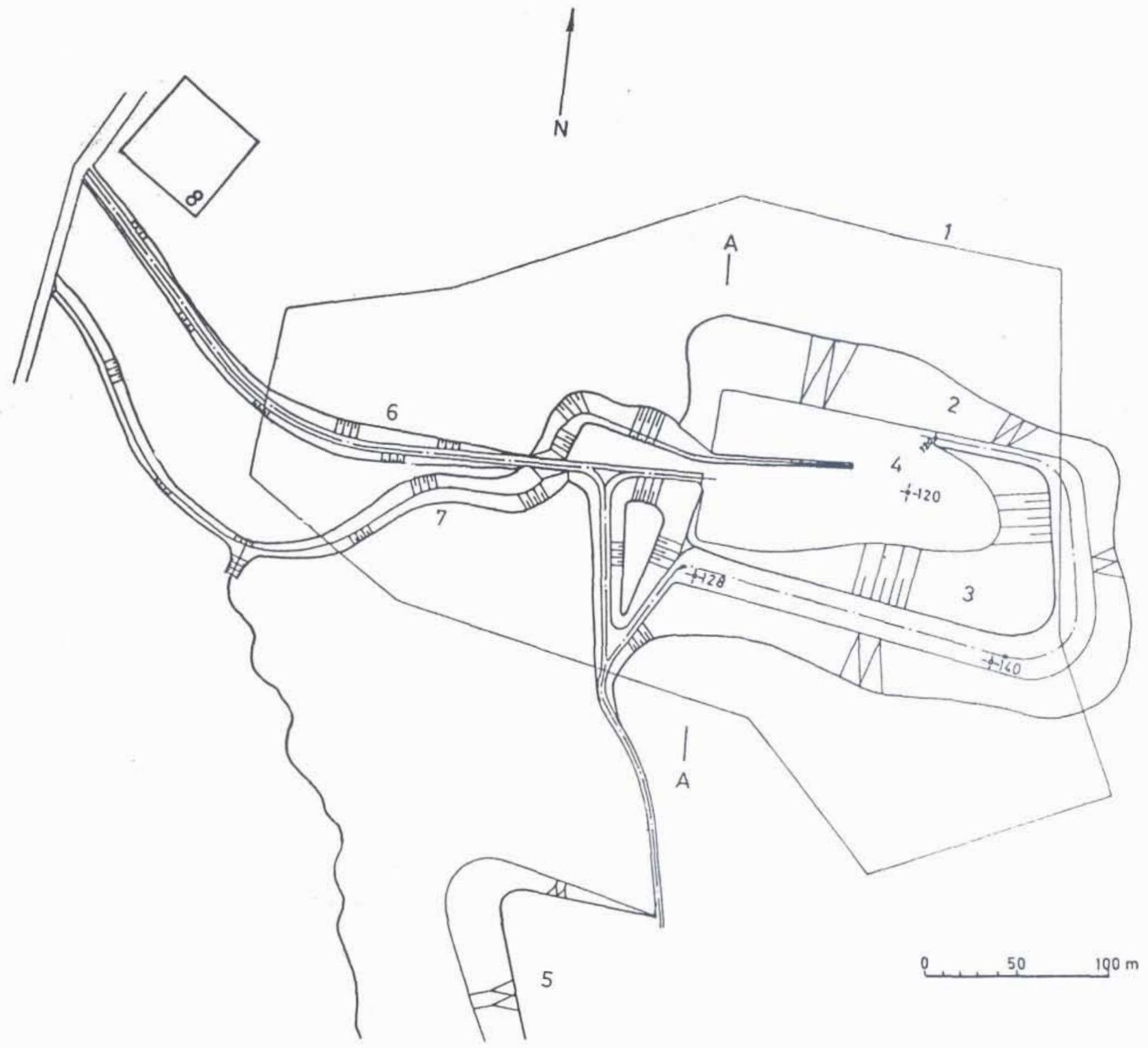

Fig. 7. Development of open pit "Vrtlinska"

1 limit line of glass sand reserves, 2 slope of overburden, 3 slope of sand, 4 loading plateau, 5 waste dump, 6 access road, 7 brook, 8 working buildings, 9 A-A position of profile on Fig. 2 . 
trailer trucks for the transport of mineral raw materials to customers. Winning and loading of glass sand is illustrated by Figs. 4 . and 8 .

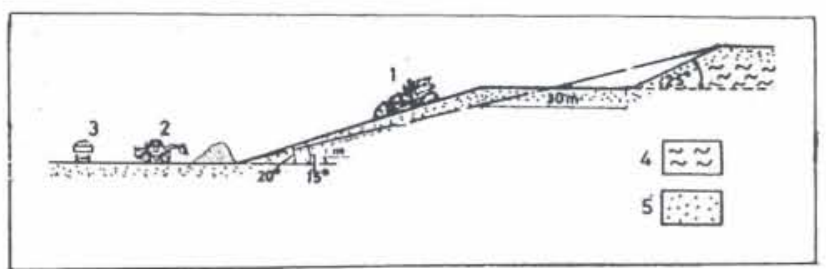

Fig. 8. Shema of winning and loading of glass sand 1 bulldozer, 2 loader, 3 truck, 4 overburden, 5 sand

The waste dump is located on the south part of the open pit in a natural valley, and divided in two levels on the elevations 145 and $160 \mathrm{~m}$. Bulldozers on the waste dump are used for flattening and compaction of material. To eliminate pore-water pressure and to insure stability of waste dump on the heights less than $2 \mathrm{~m}$ the layers of sand 5 to $10 \mathrm{~cm}$ thick are build in (Fig. 9).

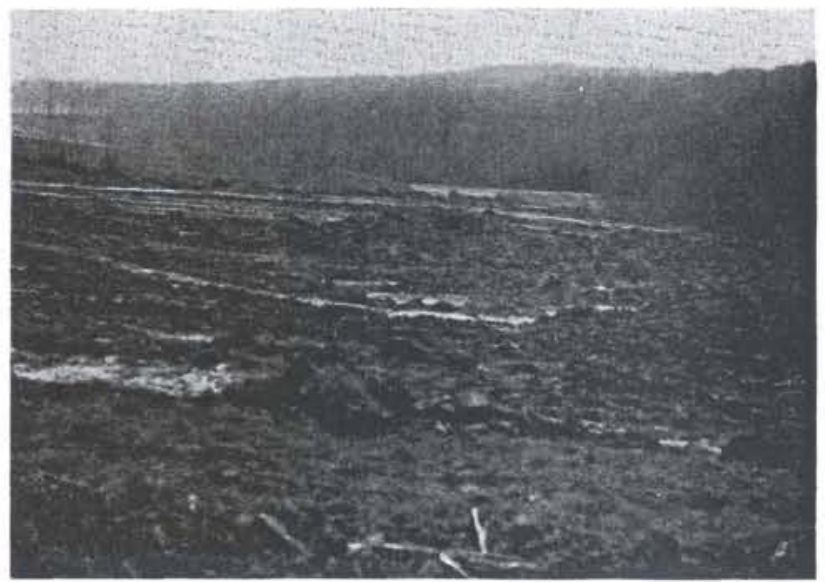

Fig. 9. View of waste dump

Exploitation of the depth part of open pit will follow after the exploitation of the height part finished and this will be separately designed. A special distinction of the exploitation in that part of the deposit is the presence of groundwater, withouth any possibility of drainage by gravitation outside the open pit boundaries. That is the reason why the beginning of exploitation under the basic elevation +120 m must be proceeded by a detailed exploration and analysis of hydrogeological characteristics of the deposit and of the broader environment in order to acquire necessary information on the groundwater regime, quantity, way of inflow and drainage conditions. According to especially worked out exploration program which will serve as the basis to conduct the mining project concerning the continuation of exploration of this glass sand deposit.

The exploration of such deposits under groundwater level can be founded on two basic technological solutions:
- exploitation in classical way with preliminary decrease of groundwater level under the elevation of deposit cut, and

- exploitation by hydraulic winning with hydraulic transport by pipe-line outside open pit boundaries.

\section{Environmental aspects}

Open pit exploitation of glass sand has no significant impacts on the environment, because it differs considerably from any other more complex mining production according to the technology of mining activities procedure within the designed boundary and to the possibility of causing demage. The nearest villages are about $300 \mathrm{~m}$ far from the open pit and they are not much exposed to impacts and changes considering eco-system, microclimatic conditions, qulity of water and air.

Prevention of dust accumulation is conducted on all origins of dustiness according to the up-to-now known and efficient methods, by using a water treatment. It is convenient that sand has sufficient natural moisture during the most of time in the year.

In the "Glass industry Lipik«, like as in other countries (Bauer, 1970, Kennedy, 1992), the quality of restauration of sand quariess have been improved in last decades. According to the conditions of space arrangement, restoration activities are also planned in quarry Vrtlinska, which are necessary to be carried out in order to eliminate disturbances in space, caused by mining exploration. Thus the angles of final slope of the height part of the open pit (above the elevation 120) and waste dump are established according to the criteria of stability protection and sliding, as well as according to the conditions of recultivation activity (afforesting) of the devasted area. The area of depth part of the open pit (lower than the elevation 120) i. e. under groundwater level is planed for a lake, supposed for sport and recreative purposes after exploitation period is over.

Received: 18. I. 1994.

Accepted: 9. VI. 1994

\section{REFERENCES}

Bauer, A. M. (1979): A Guide to Site Development and Rehabilitation of Pits and Quarries. Ontario Deparment of Mines, 60 pp. Toronto.

Kennedy, A. (1992): Advances in Mine Reclamation. Mining Magazine June, 334-338, Edenbridge.

Krkalo, E. (1985): Pronalazak i istraživanje kvarcnog pijeska "Vrtlinska" kod Cazme s posebnim osvrtom na koru trošenja granitnog masiva sjeverozapadnog obodnog područja Moslavačke gore (magistarska radnja). (Discovery and explorations of the glass sand "Vrtlinsk « near Cazma especially considering weathered crust of granite massif on the north-western skirt area of the Moslavačka gora [master thesis]). Rudarsko-geološko-naftni fakultet Sveučilišta u Zagrebu.

Vujec, S., Krkalo, E., Prokopović, S. (1987): Glavni rudarski projekt eksploatacije kremenog pijeska "Vrtlinska iznad nivoa podzemne vode (k. 120). (Mine project of the "Vrtlinska« glass sand exploitation above groundwater level [elev. 120]). Rudarsko-geološko-naftni fakultet Sveučilišta u Zagrebu, 153 pp. (Unpubl). 